\title{
Halolactibacillus halophilus gen. nov., sp. nov. and Halolactibacillus miurensis sp. nov., halophilic and alkaliphilic marine lactic acid bacteria constituting a phylogenetic lineage in Bacillus rRNA group 1
}

\author{
Morio Ishikawa, Kazuyuki Nakajima, Yuko Itamiya, Sayumi Furukawa, \\ Yasushi Yamamoto and Kazuhide Yamasato

\section{Department of Fermentation Science, Faculty of Applied Bio-Science, Tokyo University of Agriculture, 1-1 Sakuragaoka 1-chome, Setagaya-ku, Tokyo 156-8502, Japan}

Correspondence

Morio Ishikawa

m1ishika@nodai.ac.jp
Eleven novel strains of marine-inhabiting lactic acid bacteria that were isolated from living and decaying marine organisms collected from a temperate area of Japan are described. The isolates were motile with peritrichous flagella and non-sporulating. They lacked catalase, quinones and cytochromes. Fermentation products from glucose were lactate, formate, acetate and ethanol. Lactate yield as percentage conversion from glucose was affected by the $\mathrm{pH}$ of the fermentation medium: $\sim 55 \%$ at the optimal growth $\mathrm{pH}$ of $8 \cdot 0$, greater than $\sim 70 \%$ at $\mathrm{pH} 7 \cdot 0$ and less than $\sim 30 \%$ at $\mathrm{pH} 9 \cdot 0$. The molar ratio of the other three products was the same at each cultivation $\mathrm{pH}$, approximately $2: 1: 1$. Carbohydrates and related compounds were aerobically metabolized to acetate and pyruvate as well as lactate. The isolates were slightly halophilic, highly halotolerant and alkaliphilic. The optimum $\mathrm{NaCl}$ concentration for growth was $2 \cdot 0-3 \cdot 0 \%(\mathrm{w} / \mathrm{v})$, with a range of $0-25 \cdot 5 \%$. The optimum $\mathrm{pH}$ for growth was $8 \cdot 0-9 \cdot 5$, with a range of $6 \cdot 0-10 \cdot 0$. The $\mathrm{G}+\mathrm{C}$ content of the DNA was 38.5-40.7 mol\%. The isolates constituted two genomic species (DNA-DNA relatedness of less than $41 \%$ ) each characterized by sugar fermentation profiles. The cell-wall peptidoglycan of both phenotypes contained meso-diaminopimelic acid. The major cellular fatty acids were $C_{16: 0}$ and a- $C_{13: 0}$. Comparative sequence analysis of the $16 S$ rRNA genes revealed that these isolates represent novel species constituting a phylogenetic unit outside the radiation of typical lactic acid bacteria and an independent line of descent within the group composed of the halophilic/halotolerant/alkaliphilic and/or alkalitolerant species in Bacillus rRNA group 1, with $94 \cdot 8-95 \cdot 1 \%$ similarity to the genus Paraliobacillus, $93 \cdot 7-94 \cdot 1 \%$ to the genus Gracilibacillus and $93 \cdot 8-94 \cdot 2 \%$ to Virgibacillus marismortui. On the basis of possession of physiological and biochemical characteristics common to typical lactic acid bacteria within Bacillus rRNA group 1, chemotaxonomic characteristics and phylogenetic independence, a new genus and two species, Halolactibacillus halophilus gen. nov., sp. nov. and Halolatibacillus miurensis sp. nov., are proposed. The type strains are Halolactibacillus halophilus $\mathrm{M} 2-2^{\top}$ $\left(=\mathrm{DSM} 17073^{\top}=\mathrm{IAM} 15242^{\top}=\operatorname{NBRC} 100868^{\top}=\operatorname{NRIC} 0628^{\top}\right)(\mathrm{G}+\mathrm{C}$ content $40 \cdot 2 \mathrm{~mol} \%)$ and Halolactibacillus miurensis M23-1 ${ }^{\top}\left(=\mathrm{DSM} 17074^{\top}=\mathrm{IAM} 15247^{\top}=\mathrm{NBRC}\right.$ $\left.100873^{\top}=\mathrm{NRIC} 0633^{\top}\right)(\mathrm{G}+\mathrm{C}$ content $38 \cdot 5 \mathrm{~mol} \%)$.

Published online ahead of print on 15 July 2005 as DOI 10.1099/ijs.0.63713-0.

Abbreviations: HA group, halophilic/halotolerant/alkaliphilic and/or alkalitolerant group.

The GenBank/EMBL/DDBJ accession numbers for the 16S rRNA gene sequences of strains M2-2 ${ }^{\top}$ and M23-1 ${ }^{\top}$ are AB196783 and AB196784, respectively.

A phylogenetic tree constructed using the maximum-likelihood method showing the relationships between the new isolates and other related bacteria, and tables detailing the products from glucose under aerobic and anaerobic cultivation conditions and the cellular fatty acid compositions of Halolactibacillus halophilus M2-2 ${ }^{\top}$ and Halolactibacillus miurensis M23-1 $1^{\top}$ and related taxa are available as supplementary material in IJSEM Online. 
We previously reported the isolation, taxonomic characterization and phylogenetic position of a lactic acid bacterium named Marinilactibacillus psychrotolerans (Ishikawa et al., 2003b). It was isolated from marine organisms (living sponge, decaying alga and raw shellfish) and is slightly halophilic, highly halotolerant and alkaliphilic, growing preferably under the physico-chemical conditions found in sea water [total salt concentration, $3 \cdot 2-3 \cdot 8 \%(\mathrm{w} / \mathrm{v})$; $\mathrm{pH} 8 \cdot 2-8 \cdot 3$ (surface)]. For this marine-inhabiting organism, we proposed the term 'marine lactic acid bacterium'. In addition to the isolation and proposal of the genus Marinilactibacillus, a Gram-positive, spore-forming, facultatively anaerobic, halophilic, halotolerant, 'slightly' alkaliphilic and marine-inhabiting bacterium named Paraliobacillus ryukyuensis was isolated from a decaying marine alga (Ishikawa et al., 2002, 2003a). It produces lactate under anaerobic conditions and belongs to the phylogenetic group whose members have halophilic/halotolerant/alkaliphilic and/or alkalitolerant properties (Garabito et al., 1997; Heyndrickx et al., 1999; Wainø et al., 1999; Lu et al., 2001; Zhilina et al., 2001, 2002; Yoon et al., 2002) within Bacillus rRNA group 1 (Ash et al., 1991) in the phyletic assemblage of bacteria classically defined as the genus Bacillus. Most of the member species of this phylogenetic group were isolated from saline or hypersaline environments: sediments of saline lakes, hypersaline soils, solar salterns, mud of deep-sea ridge and salt fields.

In the course of isolating a marine-inhabiting lactic acid bacterium, novel halophilic and alkaliphilic lactic acid bacteria belonging to this halophilic/halotolerant/alkaliphilic and/or alkalitolerant group (henceforth referred to as the HA group) were isolated from decaying marine algae and a living sponge. Here we describe the isolation, taxonomic characterization and phylogenetic positions of the isolates, for which the names Halolactibacillus halophilus gen. nov., sp. nov. and Halolactibacillus miurensis sp. nov. are proposed.

The samples for the isolation of lactic acid bacteria were collected from Oura beach $\left(35^{\circ} 08^{\prime} \mathrm{N} 139^{\circ} 40^{\prime} \mathrm{E}\right)$ on the Miura Peninsula in Kanagawa Prefecture, in the middle of the Japanese mainland, a temperate area, in July 1998. The samples collected were living, fresh or decaying sponges, algae, shellfish, crabs and fish.

The isolates of lactic acid bacteria were obtained by enrichment culture in a $7 \% \mathrm{NaCl}$ GYPB (glucose-yeast extract-peptone-beef extract) isolation broth and poreplating on a $7 \% \mathrm{NaCl} \mathrm{GYPB}$ isolation agar ( $1.3 \%$ agar). The compositions of the media and the method used for isolation have been described previously (Ishikawa et al., 2003b). Briefly, the strains were isolated by successive enrichment and by plating. In the first enrichment culture, a small piece of the sample was soaked in medium immediately after collection and then an inoculated broth was incubated at $30^{\circ} \mathrm{C}$ for 3 days. In the second enrichment culture, a broth medium was inoculated with a portion of the first enrichment broth culture, whose $\mathrm{pH}$ had decreased to below $7 \cdot 0$, and incubated anaerobically at $30^{\circ} \mathrm{C}$ for 2 days.
Eleven bacterial strains were isolated from three kinds of decaying marine alga and a living sponge. Four isolates (M2$1, \mathrm{M} 2-2^{\mathrm{T}}, \mathrm{M} 2-3$ and M2-4) were obtained from a decaying alga. One isolate, M9-1, was from another decaying alga. Another isolate, M13-1, was from a living sponge. Five isolates (M23-1 ${ }^{\mathrm{T}}, \mathrm{M} 23-2, \mathrm{M} 23-3, \mathrm{M} 23-4$ and M23-5) were from a third kind of alga.

Marinilactibacillus psychrotolerans M13-2 ${ }^{\mathrm{T}}$ (Ishikawa et al., 2003b), Paraliobacillus ryukyuensis $\mathrm{O} 15-7^{\mathrm{T}}$ (Ishikawa et al., 2002, 2003a), Amphibacillus xylanus NRIC $1994^{\mathrm{T}}$ (Niimura et al., 1990), Amphibacillus fermentum DSM $13869^{\mathrm{T}}$ (Zhilina et al., 2001), Amphibacillus tropicus DSM $13870^{\mathrm{T}}$ (Zhilina et al., 2001), Gracilibacillus halotolerans DSM $11805^{\mathrm{T}}$ (Wainø et al., 1999) and Gracilibacillus dipsosauri DSM $11125^{\mathrm{T}}$ (Lawson et al., 1996; Wainø et al., 1999) were used as reference strains.

For cultivation and taxonomic characterization, a $2 \cdot 5 \%$ $\mathrm{NaCl}$ GYPF broth, composed of $10 \mathrm{~g}$ glucose, $5 \mathrm{~g}$ yeast extract (Oriental Yeast), 5 g Polypeptone (Nippon Seiyaku), $5 \mathrm{~g}$ Extract Bonito (fish extract; Wako Pure Chemical), $1 \mathrm{~g}$ $\mathrm{K}_{2} \mathrm{HPO}_{4}, 25 \mathrm{~g} \mathrm{NaCl}, 1 \mathrm{~g}$ sodium thioglycolate, $5 \mathrm{ml}$ salt solution $\left[\left(\mathrm{ml}^{-1}\right): 40 \mathrm{mg} \mathrm{MgSO}_{4} .7 \mathrm{H}_{2} \mathrm{O}, 2 \mathrm{mg} \mathrm{MnSO}_{4} .4 \mathrm{H}_{2} \mathrm{O}\right.$ and $2 \mathrm{mg} \mathrm{FeSO} \mathrm{O}_{4} .7 \mathrm{H}_{2} \mathrm{O}$ ] (Okada et al., 1992), and distilled water to $1000 \mathrm{ml}$, was used as the basal medium unless otherwise stated. The medium was adjusted to $\mathrm{pH} 8.5$ and sterilized by filtration. When a larger cell mass was needed for cellular component analysis, the concentration of $\mathrm{K}_{2} \mathrm{HPO}_{4}$ in the $2.5 \% \mathrm{NaCl} \mathrm{GYPF}$ broth was increased from $0 \cdot 1$ to $1 \%$ to buffer the cultivation medium and improve growth $(2 \cdot 5 \%$ $\mathrm{NaCl}$ GYPFK broth). The isolates were stored at $5{ }^{\circ} \mathrm{C}$ in this medium and transferred at 1-month intervals as described previously (Ishikawa et al., 2003b). The isolates were grown by standing cultivation at $30^{\circ} \mathrm{C}$ unless otherwise stated. Anaerobic cultivation was conducted by using AnaeroPackKenki $\left(\mathrm{CO}_{2}\right.$-generated; Mitsubishi Gas Chemical), as described previously (Ishikawa et al., 2003b). For cultivation of the reference strains the following media were used: Marinilactibacillus psychrotolerans $\mathrm{M} 13-2^{\mathrm{T}}$ and Paraliobacillus ryukyuensis $\mathrm{O} 15-\mathrm{7}^{\mathrm{T}}$, the same medium as for the isolates; Amphibacillus xylanus NRIC $1994^{\mathrm{T}}, 2 \cdot 5 \% \mathrm{NaCl}$ GYPF broth without $\mathrm{NaCl}, \mathrm{pH} 9 \cdot 0 ;$ Amphibacillus fermentum DSM $13869^{\mathrm{T}}$ and Amphibacillus tropicus DSM $13870^{\mathrm{T}}, 2 \cdot 5 \%$ $\mathrm{NaCl}$ GYPF broth but without $\mathrm{NaCl}$ and salt solution, and addition of $\left(1^{-1}\right): 0 \cdot 1 \mathrm{~g} \mathrm{MgCl}_{2}, 0 \cdot 2 \mathrm{~g} \mathrm{KCl}, 50 \cdot 4 \mathrm{~g} \mathrm{NaHCO}_{3}$ and $63.6 \mathrm{~g} \mathrm{Na}_{2} \mathrm{CO}_{3}, \mathrm{pH} 9 \cdot 5 ; \mathrm{G}$. halotolerans DSM $11805^{\mathrm{T}}$ and G. dipsosauri DSM $11125^{\mathrm{T}}$, marine broth 2216 (Difco) with addition of $10 \mathrm{~g}$ glucose $\mathrm{l}^{-1}$ and $5 \mathrm{~g} \mathrm{KCl}^{-1}$. All media were sterilized by filtration. Marinilactibacillus psychrotolerans $\mathrm{M} 13-2^{\mathrm{T}}$ and Paraliobacillus ryukyuensis $\mathrm{O} 15-7^{\mathrm{T}}$ were cultivated in the same way as the isolates. Amphibacillus species were grown by standing cultivation at $37^{\circ} \mathrm{C}$ and Gracilibacillus species by shaking at $30^{\circ} \mathrm{C}$.

Cellular morphology, cultural characteristics, motility, Gram staining and flagellation were characterized as described previously (Ishikawa et al., 2002). Spore formation was examined microscopically for cultures grown at $37^{\circ} \mathrm{C}$ 
on $2.5 \% \mathrm{NaCl}$ GYPF agar, marine agar 2216 with or without 5 p.p.m. $\mathrm{Mn}^{2+}\left(\mathrm{MnSO}_{4}\right)$, and $2 \% \mathrm{NaCl}$ yeast extract salts agar ( $\mathrm{pH} 8 \cdot 5$ ) composed of $5 \mathrm{~g}$ yeast extract, $20 \mathrm{~g} \mathrm{NaCl}, 5 \mathrm{~g}$ $\mathrm{MgSO}_{4} .7 \mathrm{H}_{2} \mathrm{O}, 2 \mathrm{~g} \mathrm{CaCl}_{2}, 1 \mathrm{~g} \mathrm{~K}_{2} \mathrm{HPO}_{4}, 5 \mathrm{ml}$ salt solution (see $2.5 \% \mathrm{NaCl}$ GYPF broth) and $15 \mathrm{~g}$ agar in 11 distilled water, by using the method described previously (Ishikawa et al., 2002). Aerobic utilization of glucose was examined by using $2.5 \% \mathrm{NaCl}$ GCY broth, composed of 10 g glucose, $5 \mathrm{~g}$ Vitamin assay Casamino acids (Difco), $0.5 \mathrm{~g}$ yeast extract, $25 \mathrm{~g} \mathrm{NaCl}, 1 \mathrm{~g} \mathrm{~K}_{2} \mathrm{HPO}_{4}, 5 \mathrm{ml}$ salt solution and distilled water in $1 \mathrm{l}$ volume, as described previously (Ishikawa et al., 2002). Aerobic cultivation was conducted by shaking in a cotton-plugged, L-shaped test tube containing $5 \mathrm{ml}$ of the medium, on a reciprocal shaker $\left(125\right.$ strokes $\left.\min ^{-1}\right)$.

Catalase activity was examined by observing the evolution of bubbles upon addition of $3 \% \mathrm{H}_{2} \mathrm{O}_{2}$ solution to aerobically or anaerobically grown cells viewed under a stereoscopic microscope. Oxidase activity, growth behaviour as a function of oxygen concentration and sugar fermentation were studied as described previously (Ishikawa et al., 2003b). Production of acid was scored as positive when the titre of $0.1 \mathrm{M} \mathrm{NaOH}$ per $5 \mathrm{ml}$ culture broth was $\geqslant 0.7 \mathrm{ml}$, as weakly positive when the titre was $\geqslant 0.5 \mathrm{ml}$ and $<0.7 \mathrm{ml}$, and as negative for titres $<0.5 \mathrm{ml}$. Tests for nitrate reduction, and production of gas from glucose, ammonia from arginine and dextran from glucose were conducted as described by Okada et al. (1992). Hydrolysis of DNA (DNase test agar; Difco), casein and gelatin (Difco) was tested using agar plate methods, as described by Gerhardt et al. (1994). Media used for the investigation of these conventional taxonomic features were supplemented with $2.5 \% \mathrm{NaCl}$ and adjusted to $\mathrm{pH} 8 \cdot 5$.

The following studies were conducted as described previously (Ishikawa et al., 2003b): growth optima and ranges of $\mathrm{NaCl}$ concentration, $\mathrm{pH}$ and temperature, and maximum and minimum concentrations of $\mathrm{NaCl}$, growth temperature and $\mathrm{pH}$. Growth optima for these physiological conditions were determined from the maximum specific growth rate, $\mu_{\max }\left(\mathrm{h}^{-1}\right)$.

Fermentation products from glucose consumed were analysed by HPLC as described previously (Ishikawa et al., 2003b). The amount of glucose was estimated by using the Somogyi method (Somogyi, 1945) or enzymically with glucose oxidase (Wako Pure Chemical). The isomeric forms of lactic acid produced were determined enzymically with D- and L-lactate dehydrogenases (Roche Diagnostics).

Products from glucose were investigated during aerobic and anaerobic cultivation. Aerobic cultivation was conducted as described above. AnaeroPack-Keep (not $\mathrm{CO}_{2}{ }^{-}$ generated; Mitsubishi Gas Chemical) was used for anaerobic cultivation. Products were analysed by HPLC as described previously (Ishikawa et al., 2003b). To investigate the effect of the initial $\mathrm{pH}$ of the anaerobic cultivation medium on the composition of products from glucose, cultivation was performed in $2.5 \% \mathrm{NaCl}$ GYPF broth buffered with
$100 \mathrm{mM}$ HEPES, with the initial $\mathrm{pH}$ adjusted to $7 \cdot 0,8 \cdot 0$ or $9 \cdot 0$. To minimize the effect of any decrease in $\mathrm{pH}$ during the fermentation, the products were analysed when the $\mathrm{OD}_{660}$ of the culture reached about $0 \cdot 20$.

Analysis of fatty acids and detection of respiratory quinones were performed by using previously described methods (Ishikawa et al., 2003b). The presence of diaminopimelic acid was determined by TLC by using the method of Hasegawa et al. (1983), as described by Okada et al. (1992). The presence of cytochrome was determined by spectrophotometry using the method described by Ohama (1982) and Niimura et al. (1987). Amounts of $300 \mathrm{mg}$ (dry weight) and $3 \mathrm{~g}$ (wet weight) of cells were used for the detection of respiratory quinones and cytochromes, respectively. Cells were cultivated aerobically by shaking.

DNA base composition was determined by analysing deoxyribonucleosides by reversed-phase HPLC (Tamaoka \& Komagata, 1984). DNA-DNA hybridization was performed using the fluorometric method of Ezaki et al. (1989). For these experiments, total genomic DNA was prepared according to the combined methods of Marmur (1961) and Saito \& Miura (1963).

Almost complete sequences of $16 \mathrm{~S}$ rRNA genes were amplified by PCR using the primers 20F (5'-AGTTTGATCATGGCTCA-3', positions 10-26) and 1540R (5'-AAGGAGGTGATCCAACCGCA-3', positions 1541-1522) (Escherichia coli numbering system; Brosius et al., 1978), as described previously (Yanagi \& Yamasato, 1993; Ishikawa et al., 2003b). The amplified products were sequenced using an ABI PRISM BigDye Terminator Cycle Sequencing ready reaction kit and an ABI PRISM model 310 Genetic Analyzer (Perkin Elmer). The following five primers were used: $20 \mathrm{~F}, 1540 \mathrm{R}, 350 \mathrm{~F}$ ( $5^{\prime}$ CCTACGGGAGGCAGCAGT-3', positions $341-358)$, 800F (5'-GTAGTCCACGCCGTAAACGA-3', positions 800-819) and 900R ( $5^{\prime}$-CGGCCGTACTCCCCAGGCGG-3' ${ }^{\prime}$, positions 898-879). Percentage similarities among the isolates, the members of the HA group and other typical lactic acid bacteria were calculated for aligned DNA sequences of 1452-1468 bases in length using the program GENETIX (SDC Software Development). Known sequences were retrieved from public databases and aligned with the newly determined sequences using the program CLUSTAL_X (Thompson et al., 1997). From the resulting multiple-sequence alignment, hypervariable regions at positions 66-103 (V1 region) and 1436-1456 (V5 region) were omitted to avoid analytical errors in constructing the tree. Unrooted phylogenetic trees were reconstructed by using the maximum-likelihood method of Felsenstein (1981), as implemented in the program fastDNAml (Olsen et al., 1984), and also from the $K_{\text {nuc }}$ values (Kimura, 1980) by using the neighbour-joining method of Saitou \& Nei (1987). The stability of the groupings was estimated by bootstrap analysis (1000 replications from the neighbour-joining dataset; Felsenstein, 1985).

All 11 newly isolated strains exhibited similar taxonomic features. Cultural and morphological characteristics and 


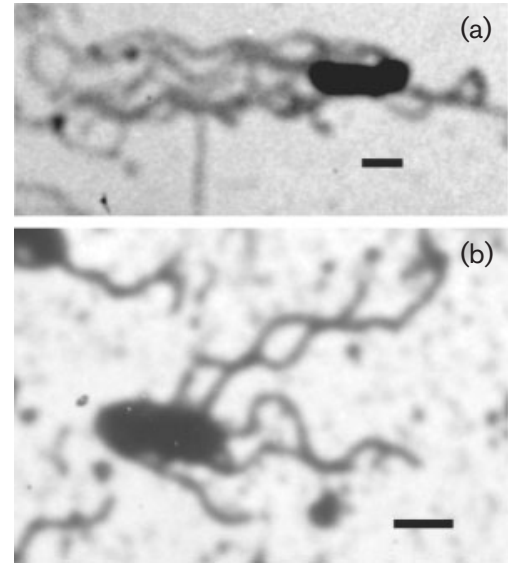

Fig. 1. Photomicrographs of cells and peritrichous flagella of Halolactibacillus halophilus $\mathrm{M} 2-2^{\top}$ (a) and Halolactibacillus miurensis $\mathrm{M} 23-1^{\top}$ (b) grown anaerobically at $30^{\circ} \mathrm{C}$ for 2 days on $2 \cdot 5 \% \mathrm{NaCl}$ GYPFK agar. Bars, $2 \mu \mathrm{m}$.

other taxonomic features are given in the descriptions of the new genus and species. Cells and peritrichous flagella of strains M2-2 ${ }^{\mathrm{T}}$ and M23-1 ${ }^{\mathrm{T}}$ are shown in Fig. 1. Spores were not produced when the cells were cultivated on $2.5 \%$ $\mathrm{NaCl}$ GYPF agar, marine agar 2216 with or without 5 p.p.m. $\mathrm{Mn}^{2+}$ or $2 \% \mathrm{NaCl}$ yeast extract salts agar. Catalase was negative for cells that were grown aerobically or anaerobically in $2.5 \% \mathrm{NaCl}$ GYPF broth, on the same medium with the concentration of glucose reduced to $0 \cdot 1 \%$, or on $2.5 \% \mathrm{NaCl}$ GYPF agar or $2 \% \mathrm{NaCl}$ yeast extract salts agar.

Under aerobic conditions, no growth was observed in $2.5 \%$ $\mathrm{NaCl} \mathrm{GCY} \mathrm{broth} \mathrm{from} \mathrm{which} \mathrm{glucose} \mathrm{was} \mathrm{excluded.} \mathrm{That} \mathrm{is,}$ in the stationary phase, the $\mathrm{OD}_{660}$ of cultures grown in $2.5 \%$ $\mathrm{NaCl}$ GCY broth was about $0 \cdot 20$, and the $\mathrm{OD}_{660}$ of those grown in the absence of glucose was less than $0 \cdot 02$. Also, in
$2 \cdot 5 \% \mathrm{NaCl}$ GYPF broth, growth was weak when the initial glucose concentration was decreased to $0.1 \%$, and did not occur when glucose was omitted. Growth occurred, but with little vigour, on a $2.5 \% \mathrm{NaCl}$ GYPF agar plate exposed to the atmosphere. The amount of growth was not affected by the oxygen concentration in the medium: the density and size of colonies that developed on semisolid medium that was evenly inoculated and statically incubated were uniform from the surface to the bottom.

A fairly wide range of carbohydrates, sugar alcohols and related carbon compounds was fermented (Table 1). These fermentation experiments revealed the presence of two phenotypes within the 11 isolates, which we designated phenotype 1 and phenotype 2 . The six isolates M2-1, M2-2 $2^{\mathrm{T}}$, M2-3, M2-4, M9-1 and M13-1 had phenotype 1, and the five isolates M23-1 ${ }^{\mathrm{T}}$, M23-2, M23-3, M23-4 and M23-5 had phenotype 2. Phenotypes 1 and 2 were distinguished on the basis of the following utilization pattern of carbon compounds: phenotype 1 strains did not ferment Larabinose, D-xylose, D-melezitose or inulin but did ferment glycerol, whereas phenotype 2 strains fermented these sugars and weakly fermented glycerol. Sodium gluconate was fermented without the production of gas by all the isolates.

The optimum $\mathrm{NaCl}$ concentrations for growth were between $2.0 \%(0.34 \mathrm{M})$ and $3.0 \%(0.51 \mathrm{M})(1.5-3.0 \%$ for strains M9-1 and M23-5) for phenotype 1 and between $2.5 \%(0.43 \mathrm{M})$ and $3.0 \%$ for phenotype 2 . The maximum specific growth rates, $\mu_{\max }\left(\mathrm{h}^{-1}\right)$, of strain $\mathrm{M} 2-2^{\mathrm{T}}$, phenotype 1 , were 0.18 in $0 \%, 0.22$ in $0.5 \%, 0.30$ in $1 \cdot 0 \%, 0.46$ in $1.5 \%, 0.48$ in $2 \cdot 0 \%, 0.54$ in $2.5 \%, 0.40$ in $3.0 \%, 0.40$ in $3.75 \%$, and 0.40 in $5.0 \% \mathrm{NaCl}$. Those of strain M23- $1^{\mathrm{T}}$, phenotype 2, were 0.40 in $0 \%, 0 \cdot 44$ in $0.5 \%$, 0.56 in $1.0 \%, 0.56$ in $1.5 \%, 0.56$ in $2.0 \%, 0.70$ in $2.5 \%$, 0.60 in $3.0 \%, 0.48$ in $3.75 \%$, and 0.48 in $5.0 \% \mathrm{NaCl}$. The strains of phenotype 1 were able to grow between 0 and $23 \cdot 5-24 \cdot 0 \%(4 \cdot 02-4 \cdot 11 \mathrm{M}) \mathrm{NaCl}$ and those of phenotype 2 between 0 and $25 \cdot 5 \%(4 \cdot 36 \mathrm{M}) \mathrm{NaCl}$.

Table 1. Profiles of sugar fermentation of the 11 new isolates

Fermentations were scored as: +, positive; -, negative; W, weakly positive (as defined in Methods). All 11 strains ferment D-glucose, D-fructose, D-galactose, D-mannose, D-cellobiose, lactose, maltose, melibiose, sucrose, D-trehalose, D-raffinose, D-mannitol, starch, methyl $\alpha$-D-glucoside, D-salicin and sodium gluconate, but do not ferment adonitol, myo-inositol, dulcitol or D-sorbitol.

\begin{tabular}{|c|c|c|c|c|c|c|c|c|c|c|c|}
\hline Carbon compound & \multicolumn{6}{|c|}{ Phenotype 1} & \multicolumn{5}{|c|}{ Phenotype 2} \\
\hline D-Arabinose & - & - & - & - & - & - & - & - & $\mathrm{w}$ & - & - \\
\hline D-Ribose & + & + & + & + & + & - & + & + & + & + & + \\
\hline D-Xylose & - & - & - & - & - & - & + & + & + & + & + \\
\hline Glycerol & + & + & + & + & + & + & $\mathrm{W}$ & $\mathrm{W}$ & $\mathrm{W}$ & $\mathrm{W}$ & $\mathrm{W}$ \\
\hline Inulin & - & - & - & - & - & - & + & + & + & + & + \\
\hline
\end{tabular}


The isolates were thus slightly halophilic (Kushner, 1978; Kushner \& Kamekura, 1988) and highly halotolerant. These characteristics are the physiological features common to most members of the HA group. Other than the present isolates, only a few taxa of lactic acid bacteria that are characteristically halophilic and highly halotolerant (able to grow at $\mathrm{NaCl}$ concentrations $>15 \%$ ) have been described to date: Tetragenococcus halophilus and Tetragenococcus muriaticus isolated from salted foods (Iizuka \& Yamasato, 1959; Satomi et al., 1997), Marinilactibacillus psychrotolerans isolated from marine organisms (Ishikawa et al., 2003b), and Alkalibacterium olivapovliticus isolated from alkaline edibleolive wash-water (Ntougias \& Russell, 2001). Weissella halotolerans, which was isolated from meat products, has a salt tolerance of $14 \%$ (Kandler et al., 1983).

The initial medium $\mathrm{pH}$ that resulted in optimum growth was between $8 \cdot 0$ and $9 \cdot 0$ for phenotype 1 and $9 \cdot 5$ for phenotype 2. No growth was observed in media for which the initial $\mathrm{pH}$ was $\leqslant 6 \cdot 0$ or $\geqslant 10 \cdot 0$ for phenotype 1 , or $\leqslant 5 \cdot 5$ or $\geqslant 10 \cdot 5$ for phenotype 2 . For strain $\mathrm{M} 2-2^{\mathrm{T}}$, phenotype 1 , the maximum specific growth rates $\left(\mathrm{h}^{-1}\right)$ were 0.38 at $\mathrm{pH} 7 \cdot 0,0 \cdot 40$ at $\mathrm{pH} 7 \cdot 5,0 \cdot 42$ at $\mathrm{pH} 8 \cdot 0,0 \cdot 52$ at $\mathrm{pH} 8 \cdot 5,0 \cdot 50$ at $\mathrm{pH} 9 \cdot 0$ and $0 \cdot 14$ at $\mathrm{pH} 9 \cdot 5$. For strain $\mathrm{M} 23-1^{\mathrm{T}}$, phenotype 2 , they were $0 \cdot 46$ at $\mathrm{pH} 7 \cdot 0,0 \cdot 46$ at $\mathrm{pH} 7 \cdot 5,0 \cdot 46$ at $\mathrm{pH} 8 \cdot 0$, 0.46 at $\mathrm{pH} 8 \cdot 5,0.48$ at $\mathrm{pH} 9 \cdot 0,0 \cdot 68$ at $\mathrm{pH} 9 \cdot 5$ and 0.40 at $\mathrm{pH} 10 \cdot 0$. The final $\mathrm{pH}$ of cultures in $2.5 \% \mathrm{NaCl}$ GYPF broth reached $5 \cdot 2-6 \cdot 0$, which was $0 \cdot 5-1 \cdot 3 \mathrm{pH}$ units lower than the minimum $\mathrm{pH}$ required to initiate growth. According to Jones et al. (1994), alkaliphiles are organisms that grow optimally at $\mathrm{pH}$ values greater than 8 . The isolates were alkaliphiles, as they grew optimally at $\mathrm{pH}$ values between $8 \cdot 0$ and $9 \cdot 0$ (phenotype 1 ) or $9 \cdot 5$ (phenotype 2 ).

Commonly occurring lactic acid bacteria are comparatively acid tolerant (their broth cultures attaining a final $\mathrm{pH}$ value $<3.0$ ) and grow optimally at neutral to slightly acid $\mathrm{pH}$, such as $\mathrm{pH} 6 \cdot 0$. Although the isolates produce acid, their growth optima lie considerably to the alkaline side, and the $\mathrm{pH}$ has to be $>6.0$ for growth initiation, both of which are uncommon characteristics among typical lactic acid bacteria. Marinilactibacillus psychrotolerans (Ishikawa et al., 2003b) and Alkalibacterium olivapovliticus (Ntougias \& Russell, 2001) are two other organisms that are not acid tolerant and not neutrophilic, but are alkaliphilic lactic acid bacteria. In the HA group, Amphibacillus xylanus, which was isolated from an alkaline compost of manure with grass and rice straw and has an energy metabolism conforming to that of the isolates (discussed later), is also alkaliphilic, growing optimally at $\mathrm{pH} 8 \cdot 0-10 \cdot 0$ (Niimura et al., 1990). Pediococcus urinaeequi, which was described as being isolated from horse urine, grows optimally at $\mathrm{pH} 8 \cdot 5-9 \cdot 0$, as deduced from the amount of acid produced in buffered broth cultures that were started at different initial $\mathrm{pH}$ values (Nakagawa \& Kitahara, 1959).

The strains reported here are marine inhabitants, as they were isolated from living and decaying marine organisms and had physiological properties consistent with the physico-chemical conditions found in sea water [total salt concentration $3 \cdot 2-3 \cdot 8 \%(\mathrm{w} / \mathrm{v}), \mathrm{pH} 8 \cdot 2-8 \cdot 3$ (surface)]. That is, they grow optimally in $2 \cdot 0-3 \cdot 0 \% \mathrm{NaCl}$ (and can grow in $0-25 \cdot 5 \% \mathrm{NaCl}$ ) and at $\mathrm{pH} 8 \cdot 0-9 \cdot 5$ (and can grow at a $\mathrm{pH}$ range of $6 \cdot 0-10 \cdot 0)$. Isolation and taxonomic studies of lactic acid bacteria from marine environments are few to date and have generally been confined to isolates from cultured fish (Ringø \& Gatesoupe, 1998; Gatesoupe, 1999). Recently, members of the genus Marinilactibacillus have been isolated: Marinilactibacillus sp. from coastal sub-seafloor sediment of the Okhotsk Sea (Inagaki et al., 2003) and Marinilactibacillus piezotolerans from deep sub-seafloor sediment of the Nankai Trough (Toffin et al., 2005). Marinilactibacillus psychrotolerans, which has been isolated from a decaying marine alga, a living sponge and a fresh shellfish, is a marine-inhabiting lactic acid bacterium with growth optima at $2 \cdot 0-3 \cdot 75 \%$ $\mathrm{NaCl}$ and $\mathrm{pH}$ 8.5-9.0 (Ishikawa et al., 2003b). For such organisms, Ishikawa et al. (2003b) proposed the term 'marine lactic acid bacteria'. Thus, the present isolates can be regarded as additional representatives of marine lactic acid bacteria on the basis of habitat, physiological properties and lactic acid fermentation (described later).

The optimum growth temperatures for the isolates were $30-37^{\circ} \mathrm{C}$ (phenotype 1) and $37-40^{\circ} \mathrm{C}$ (phenotype 2). The maximum specific growth rates $\left(\mathrm{h}^{-1}\right)$ of strain $\mathrm{M} 2-2^{\mathrm{T}}$, phenotype 1 , were 0.48 at $25^{\circ} \mathrm{C}, 0.58$ at $30^{\circ} \mathrm{C}, 0.60$ at $37^{\circ} \mathrm{C}$, 0.42 at $40{ }^{\circ} \mathrm{C}$ and 0.06 at $42.5^{\circ} \mathrm{C}$. Those of strain M23- $1^{\mathrm{T}}$, phenotype 2 , were 0.62 at $25^{\circ} \mathrm{C}, 0.64$ at $30^{\circ} \mathrm{C}, 0.74$ at $37^{\circ} \mathrm{C}$, 0.74 at $40^{\circ} \mathrm{C}$ and $0 \cdot 18$ at $42 \cdot 5^{\circ} \mathrm{C}$. Growth occurred between $5-10$ and $40{ }^{\circ} \mathrm{C}$ and between $5\left(-1.8^{\circ} \mathrm{C}\right.$ for strain M23-3) and $45^{\circ} \mathrm{C}$ for phenotypes 1 and 2 , respectively.

The fermentation products of glucose and the effects of the initial $\mathrm{pH}$ of the fermentation medium were investigated. Under anaerobic cultivation in $2.5 \% \mathrm{NaCl}$ GYPF broth, the isolates produced lactate in yields of $50-60 \%$ of the amount of glucose consumed, depending on the isolate. The other end-products were formate, acetate and ethanol in a molar ratio of approximately $2: 1: 1$. No gas was produced. The Lisomer of lactate was $80-95 \%$ of the total lactate produced. The amount of lactate relative to that of the other three products was markedly affected by the initial $\mathrm{pH}$ of the fermentation medium. For the representative selected strains $\mathrm{M} 2-2^{\mathrm{T}}$ (phenotype 1) and M23- $1^{\mathrm{T}}$ (phenotype 2), the products from glucose in relation to the $\mathrm{pH}$ of the medium were determined by using buffered media. The lactate yield relative to glucose consumed by strain $\mathrm{M} 2-2^{\mathrm{T}}$ at $\mathrm{pH} 8 \cdot 0,57 \%$, increased to $75 \%$ at the more acidic $\mathrm{pH} 7 \cdot 0$, whereas it decreased remarkably to $22 \%$ at the more alkaline $\mathrm{pH} 9 \cdot 0$; that of strain $\mathrm{M} 23-1^{\mathrm{T}}$ at suboptimum $\mathrm{pH} 9 \cdot 0,37 \%$, increased at more acidic $\mathrm{pH}$ values, $57 \%$ at $\mathrm{pH} 8.0$ and $65 \%$ at $\mathrm{pH} 7 \cdot 0$ (Table 2). For each of the initial cultivation $\mathrm{pH}$ values, the drop in $\mathrm{pH}$ value at the point of product analysis was $\leqslant 0.5 \mathrm{pH}$ units. At all $\mathrm{pH}$ values, carbon recovery from glucose consumed was about $100 \%$, and the molar ratios of formate, acetate and ethanol produced were generally approximately $2: 1: 1$ (Table 2). 
Table 2. Effect of initial $\mathrm{pH}$ of the culture medium on the product balance of glucose fermentation by the representative strains $M 2-2^{\top}$ and $M 23-1^{\top}$

\begin{tabular}{|c|c|c|c|c|c|c|}
\hline \multirow[t]{2}{*}{ Strain } & \multicolumn{4}{|c|}{ End-products [mol (mol glucose $\left.)^{-1}\right]$} & \multirow{2}{*}{$\begin{array}{l}\text { Lactate yield } \\
\text { from consumed } \\
\text { glucose }(\%)\end{array}$} & \multirow{2}{*}{$\begin{array}{c}\text { Carbon } \\
\text { recovery } \\
(\%)\end{array}$} \\
\hline & Lactate & Formate & Acetate & Ethanol & & \\
\hline \multicolumn{7}{|l|}{ M2-2 ${ }^{\mathrm{T}}$} \\
\hline pH 7 & $1 \cdot 50$ & $0 \cdot 73$ & $0 \cdot 27$ & $0 \cdot 16$ & 75 & 101 \\
\hline $\mathrm{pH} 8$ & $1 \cdot 13$ & $0 \cdot 81$ & $0 \cdot 37$ & $0 \cdot 46$ & 57 & 98 \\
\hline pH 9 & $0 \cdot 45$ & $1 \cdot 84$ & $0 \cdot 74$ & $0 \cdot 47$ & 22 & 93 \\
\hline \multicolumn{7}{|c|}{ M23-1 ${ }^{\mathrm{T}}$} \\
\hline pH 7 & $1 \cdot 30$ & $0 \cdot 76$ & $0 \cdot 28$ & $0 \cdot 18$ & 65 & 93 \\
\hline pH 8 & $1 \cdot 13$ & $0 \cdot 81$ & $0 \cdot 45$ & $0 \cdot 53$ & 57 & 103 \\
\hline pH 9 & $0 \cdot 73$ & $1 \cdot 28$ & $0 \cdot 51$ & $0 \cdot 32$ & 37 & 86 \\
\hline \multicolumn{7}{|c|}{$\begin{array}{l}\text { Marinilactibacillus } \\
\text { psychrotolerans } \\
\text { M13-2 }^{\mathrm{T} \star}\end{array}$} \\
\hline pH 7 & $2 \cdot 02$ & $0 \cdot 15$ & $0 \cdot 04$ & $0 \cdot 05$ & 101 & 107 \\
\hline pH 8 & $1 \cdot 50$ & $0 \cdot 52$ & $0 \cdot 20$ & $0 \cdot 19$ & 75 & 97 \\
\hline pH 9 & $1 \cdot 29$ & $0 \cdot 81$ & $0 \cdot 35$ & $0 \cdot 20$ & 66 & 98 \\
\hline
\end{tabular}

${ }^{*}$ Data from Ishikawa et al. (2003b).

The similar alkaliphilic lactic acid bacteria Marinilactibacillus psychrotolerans and Alkalibacterium olivapovliticus likewise produce formate, acetate and ethanol in addition to lactate under anaerobic conditions, and their product ratios were similarly affected by the initial $\mathrm{pH}$ of the fermentation medium (Ishikawa et al., 2003b). Also, in the lactateproducing facultative anaerobes Exiguobacterium aurantiacum (which lies in the phylogenetic radiation of 'classical' Bacillus) and Paraliobacillus ryukyuensis (which belongs to the HA group), glucose fermentation responded similarly to $\mathrm{pH}$ changes in the cultivation medium (Gee et al., 1980; Collins et al., 1983; Ishikawa et al., 2002), as for the present isolates. Alternation of product composition in glucose fermentation (i.e., decreased lactate production and increased production of the other three products) at alkaline $\mathrm{pH}$ and at limited glucose concentrations has also been reported for homofermentative lactic acid bacteria such as Streptococcus liquefaciens (Enterococcus faecalis), Streptococcus mutans, Streptococcus sanguinis and Lactobacillus bulgaricus (Lactobacillus delbrueckii subsp. bulgaricus) (Gunsalus \& Niven, 1942; Carlsson \& Griffith, 1974; Rhee \& Pack, 1980). In these bacteria, pyruvate is converted to lactate by lactate dehydrogenase and to formate, acetate and ethanol by pyruvateformate lyase at a molar ratio of $2: 1: 1$ : the product balance depends on the relative activities of the two enzymes involved (Carlsson \& Griffith, 1974; Yamada \& Carlsson, 1975; Axelsson, 1993). Kandler \& Weiss (1986) classified lactic acid fermentation in the genus Lactobacillus into three groups: group I, obligately homofermentative lactobacilli; group II, facultatively heterofermentative lactobacilli; and group III, obligately heterofermentative lactobacilli. Whereas Lactobacillus species belonging to group II produce lactate almost exclusively from hexose under their usual growth conditions, they produce lactate, formate, acetate and ethanol under glucose limitation (Kandler \& Weiss, 1986). It is noteworthy that the present isolates, as well as Marinilactibacillus psychrotolerans and Alkalibacterium olivapovliticus, are lactic acid bacteria in which pyruvate-formate lyase would be active to produce formate, acetate and ethanol under their normal growth conditions.

Products from glucose under aerobic cultivation conditions were acetate, pyruvate and lactate, but formate and ethanol were not produced by the isolates or Marinilactibacillus psychrotolerans $\mathrm{M} 13-2^{\mathrm{T}}$ (see Supplementary Table S1 in IJSEM Online). Carbon recovery was not balanced. This imbalance can be ascribed to $\mathrm{CO}_{2}$ generation, if the metabolism of Amphibacillus xylanus, another facultatively anaerobic bacterium belonging to the HA group (Niimura et al., 1990), is relevant. Amphibacillus xylanus lacks catalase, cytochromes and quinones. This bacterium has both an anaerobic pathway for glucose metabolism and an oxidative metabolic pathway that is not mediated by the respiratory chain (Niimura et al., 1989). Under anaerobic conditions, the end-products from glucose are formate, acetate and ethanol in a molar ratio of $2: 1: 1$. Acetyl CoA and formate are formed from pyruvate, mediated by pyruvate-formate lyase. NADH produced through glycolysis is regenerated to NAD by aldehyde dehydrogenase and alcohol dehydrogenase. Under aerobic conditions, acetate and $\mathrm{CO}_{2}$ are the end-products from glucose. Coupled with the conversion of pyruvate to acetyl CoA, NAD is reduced to NADH by pyruvate dehydrogenase and $\mathrm{CO}_{2}$ is produced. NADH produced through glycolysis and pyruvate oxidation is regenerated to $\mathrm{NAD}$ by the NADH oxidase/peroxidase system, using $\mathrm{O}_{2}$ as an electron acceptor. Consequently, ethanol production with generation of $\mathrm{NADH}$ does not occur under aerobic conditions. If we assume that 
equimolar production of acetate and $\mathrm{CO}_{2}$ also occurs in the isolates and in Marinilactibacillus psychrotolerans, carbon recovery under aerobic conditions can be calculated as 93-97\%.

The existence of the same oxidative pathway as that of Amphibacillus xylanus has been reported in several other species of lactic acid bacteria. For example, S. mutans has an oxidative pathway that is mediated by the NADH oxidase system (Fukui et al., 1988). Liu et al. (2002) concluded that Trichococcus flocculiformis, which lacks cytochromes, also has this oxidative pathway, on the basis of an analysis of its metabolites and ATP production under air. Sakamoto \& Komagata (1996) also reported NADH oxidase and NADH peroxidase activities and acetate production under aerobic conditions in the homofermentative lactic acid bacteria Lactobacillus, Pediococcus and Streptococcus, and in the heterofermentative lactic acid bacteria Leuconostoc. The isolates and Amphibacillus xylanus belong to the HA group in the phyletic radiation of 'classical' Bacillus, and Marinilactibacillus psychrotolerans and the lactic acid bacteria mentioned here belong to the radiation in which the usual lactic acid bacteria are located. All of these may have an identical oxidative metabolic pathway, even though they are located in different phyletic radiations. Thus, this metabolic system might be a common feature of aerotolerant fermentative bacteria.
The isolates possessed meso-diaminopimelic acid in the cellwall peptidoglycan, as demonstrated by TLC. The peptidoglycan type of the genera belonging to the HA group is type A $1 \gamma$, meso-diaminopimelic acid direct linkages, except for Halobacillus species and Filobacillus species. The cellular fatty acid compositions of the representative strains $\mathrm{M} 2-2^{\mathrm{T}}$ (phenotype 1) and M23-1 ${ }^{\mathrm{T}}$ (phenotype 2) were characterized by straight-chain, anteiso-branched saturated, iso-branched saturated and monounsaturated acids (see Supplementary Table S2 in IJSEM Online). The major cellular fatty acids were $a-C_{13: 0}$ and $C_{16: 0}$. Among the members of the HA group and other 'classical' Bacillus species that possess anteiso fatty acids as common features, possession of a- $\mathrm{C}_{13: 0}$ as a major component is characteristic of the isolates (see Supplementary Table S2 in IJSEM Online).

Respiratory quinones and cytochromes were not present in strains $\mathrm{M} 2-2^{\mathrm{T}}$ and $\mathrm{M} 23-1^{\mathrm{T}}$. Along with Amphibacillus xylanus, the absence of these respiratory components is characteristic among members of the HA group, which is composed of many aerobic and facultatively anaerobic genera and species.

The $\mathrm{G}+\mathrm{C}$ contents of the DNA of the new isolates fell into narrow ranges: $39 \cdot 6-40 \cdot 7 \mathrm{~mol} \%$ for phenotype 1 and 38.5-40.0 mol\% for phenotype 2 (Table 3 ). The DNADNA relatedness values among the strains of phenotype 1

Table 3. DNA base composition and DNA-DNA relatedness among the new isolates and related taxa

\begin{tabular}{|c|c|c|c|}
\hline \multirow[t]{2}{*}{ Strain } & \multirow{2}{*}{$\begin{array}{c}\text { DNA base } \\
\text { composition } \\
(\text { mol\% G+C })^{\star}\end{array}$} & \multicolumn{2}{|c|}{ Relative binding (\%) of DNA from } \\
\hline & & $\mathrm{M} 2-2^{\mathrm{T}}$ & M23-1 ${ }^{\mathrm{T}}$ \\
\hline \multicolumn{4}{|l|}{ Phenotype 1} \\
\hline M2-1 & $39 \cdot 6$ & 84 & ND \\
\hline $\mathrm{M} 2-2^{\mathrm{T}}$ & $40 \cdot 2$ & 100 & 35 \\
\hline M2-3 & $40 \cdot 0$ & 82 & ND \\
\hline $\mathrm{M} 2-4$ & $40 \cdot 2$ & 87 & ND \\
\hline M9-1 & $40 \cdot 7$ & 92 & 21 \\
\hline M13-1 & $40 \cdot 5$ & 85 & 29 \\
\hline \multicolumn{4}{|l|}{ Phenotype 2} \\
\hline M23-1 ${ }^{\mathrm{T}}$ & $38 \cdot 5$ & 41 & 100 \\
\hline M23-2 & $39 \cdot 2$ & ND & 96 \\
\hline M23-3 & $39 \cdot 7$ & ND & 79 \\
\hline M23-4 & $38 \cdot 7$ & ND & 82 \\
\hline M23-5 & $40 \cdot 0$ & ND & 83 \\
\hline Paraliobacillus ryukyuensis $\mathrm{O} 15-7^{\mathrm{T}}$ & $35 \cdot 6^{a}$ & 4 & 4 \\
\hline Amphibacillus xylanus JCM $7361^{\mathrm{T}}$ & $36 \cdot 0^{b}$ & 5 & 4 \\
\hline Amphibacillus fermentum DSM $13869^{\mathrm{T}}$ & $41 \cdot 5^{c}$ & 22 & 14 \\
\hline Amphibacillus tropicus DSM $13870^{\mathrm{T}}$ & $39 \cdot 2^{c}$ & 24 & 21 \\
\hline G. halotolerans DSM $11805^{\mathrm{T}}$ & $39 \cdot 4^{d}$ & 3 & 2 \\
\hline G. dipsosauri DSM $11125^{\mathrm{T}}$ & $35 \cdot 6^{e}$ & 4 & 4 \\
\hline
\end{tabular}

ND, Not determined.

${ }^{*}$ Data from: $a$, Ishikawa et al. (2002); b, Niimura et al. (1990); c, Zhilina et al. (2001); d, Wainø et al. (1999);

$e$, Lawson et al. (1996). 
were $82-92 \%$ and those among the strains of phenotype 2 were $79-96 \%$. Isolates M2-2 ${ }^{\mathrm{T}}$, M9-1 and M13-1 of phenotype 1 showed low DNA-DNA relatedness values $(35,21$ and $29 \%$, respectively) to $\mathrm{M} 23-1^{\mathrm{T}}$ from phenotype 2 , and M23- $1^{\mathrm{T}}$ from phenotype 2 also showed low DNA-DNA relatedness $(41 \%)$ to $\mathrm{M} 2-2^{\mathrm{T}}$ from phenotype 1 (Table 3 ). On the basis of their DNA-DNA relatedness, the isolates constitute two genomic species; furthermore, the strains within each genomic species correspond to the two phenotypes that were determined from the sugar fermentation profiles (Table 1). Levels of DNA-DNA relatedness between the two type strains and strains of the phylogenetically related genera Amphibacillus, Gracilibacillus and Paraliobacillus were $2-24 \%$, as low as levels between distinct species (Table 3).

Complete sequences of the 16S rRNA gene, 1491 bases in length and covering positions 41-1508 (Escherichia coli numbering system; Brosius et al., 1978), were determined for the type strain of each phenotype. The sequences were aligned and compared with the sequences of 29 species of related bacteria and lactic acid bacteria from public databases. The $16 \mathrm{~S}$ rRNA gene sequence similarity value between M2-2 ${ }^{\mathrm{T}}$ (phenotype 1) and M23-1 $1^{\mathrm{T}}$ (phenotype 2) was $99 \cdot 1 \%$. Pairwise analysis revealed that the new isolates exhibited the highest similarity values to the genera Paraliobacillus (94.8-95.1\% similarity), Amphibacillus (92.9-94.3\%), Gracilibacillus (93.7-94.1\%) and Virgibacillus marismortui $(93 \cdot 8-94 \cdot 2 \%)$. A phylogenetic tree constructed by using the neighbour-joining method showed that the two phenotypes constitute an independent line of descent within the HA group in rRNA group 1 of the phyletic group classically defined as the genus Bacillus, and occupy a phylogenetic position that is closely related to the genera Paraliobacillus, Gracilibacillus and Amphibacillus (Fig. 2). This relationship between the isolates and these three genera was also found in the tree constructed using the maximum-likelihood algorithm (see Supplementary Fig. S1 in IJSEM Online).

The isolates possess all the essential characteristics of lactic acid bacteria that have been attributed to the most typical lactic acid bacteria, including production of lactic acid

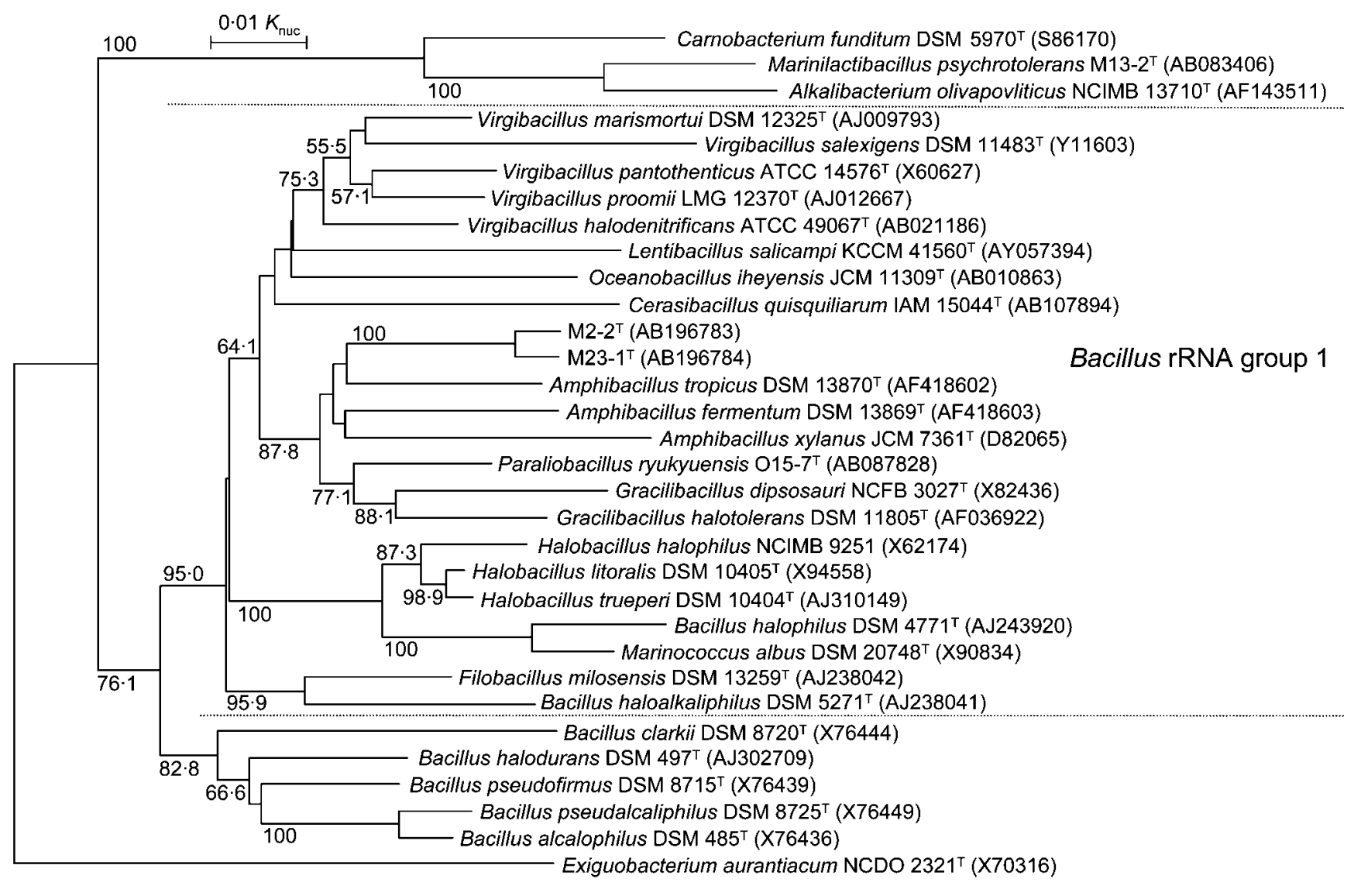

Fig. 2. Phylogenetic relationships between the new isolates and some other related bacteria, based on 16S rRNA gene sequences. Exiguobacterium aurantiacum NCDO $2321^{\top}$ was used as an outgroup. The tree, constructed by using the neighbour-joining method, is based on comparison of approximately 1380 nucleotides. Bar, $0.01 K_{\text {nuc }}$. Bootstrap values, expressed as a percentage of 1000 replications, are given at branching points; only values above $50 \%$ are shown. Bacillus rRNA group 1 according to Ash et al. (1991) is shown. 
through the Embden-Meyerhof pathway and lack of catalase, quinones, cytochromes and respiratory metabolism, but are novel lactic acid bacteria in terms of phylogeny. Typical lactic acid bacteria can be considered to have evolved retrogressively from facultative anaerobes as close ancestors. This assumption is supported by several findings. For example, Streptococcus faecalis (Enterococcus faecalis) has a haem-dependent cytochrome (Whittenbury, 1964; BryanJones \& Whittenbury, 1969). Whittenbury (1964) argued that its haem-dependent cytochrome may be a rudimentary respiratory system. In several lactic acid bacteria, enzymes involved in the TCA cycle, cytochromes, haem-dependent catalase and quinones, have been found (Whittenbury, 1964; Pritchard \& Wimpenny, 1978; Morishita et al., 1999; Wang et al., 2000). The present isolates also could have evolved to lactic acid bacteria by following independent but similar evolutionary processes within the HA group, while retaining physiological characteristics consistent with the physico-chemical factors of salt concentration and $\mathrm{pH}$ that prevail in marine environments. This hypothetical consideration is supported by the close relationship between the new isolates and, on the one hand, Paraliobacillus ryukyuensis, which has catalase, quinones and cytochromes but requires sugars for growth under both aerobic and anaerobic conditions and performs lactic acid fermentation, and, on the other, Amphibacillus xylanus, which lacks catalase, quinones and cytochromes and produces formate, acetate and ethanol via the Embden-Meyerhof pathway. The HA group should be an interesting phylogenetic group for studying the possible evolution of a common ancestor to divergent forms, as it is a compact cluster and includes aerobes, facultative anaerobes and lactic acid bacteria, rods and cocci, and has various behaviours in relation to salinity and $\mathrm{pH}$.

The present strains that were isolated from decaying algae and a living sponge are marine-inhabiting lactic acid bacteria that are slightly halophilic, extremely halotolerant and alkaliphilic. The isolates constitute an independent phylogenetic lineage within the HA group, which is in rRNA group 1, one of the phyletic groups classically defined as the genus Bacillus. The HA group is composed of 11 genera, most of which inhabit saline to hypersaline environments. Each of the genera or species is characterized by diverse features: oxidative and/or fermentative metabolism, bacilli or cocci in cellular morphology, spore formation and combinations of halophilic, halotolerant, alkaliphilic and alkalitolerant properties. The isolates differ from all members of the HA group in that they carry out aerobic and anaerobic energy metabolism (except for Virgibacillus, Paraliobacillus and Amphibacillus, which ferment sugars). Similar to Paraliobacillus and Amphibacillus, the present isolates also differ in that they require glucose (carbohydrates and related compounds) for growth even under aerobic conditions. They can be distinguished from the genus Virgibacillus by their lack of catalase and quinone and by their fatty acid compositions and from the genus Paraliobacillus by their lack of catalase, quinones and cytochromes (the presence of cytochromes in Paraliobacillus was confirmed in this study). Although they share the properties of lack of catalase, cytochrome and quinone, and comparable energy metabolism with Amphibacillus xylanus, they can be distinguished from it by their fatty acid compositions, lack of spore formation and the effects of salt concentration and $\mathrm{pH}$ on growth.

The isolates were distinguished from all members of the HA group by their combination of morphological, physiological, biochemical and chemotaxonomic features (Table 4). The isolates conformed to two genera in the group of typical lactic acid bacteria, Marinilactibacillus and Alkalibacterium, with respect to the phenotypic properties of cellular morphology, motility, halophilic and halotolerant properties and lactic acid fermentation pattern. However, they could be distinguished from these genera by the chemotaxonomic characteristics of peptidoglycan type and cellular fatty acid composition. The isolates could be distinguished from other homofermentative lactic acid rods (Lactobacillus, Carnobacterium and Paralactobacillus), depending on the species, by motility, cellular fatty acid composition, DNA base composition and halophilic and alkaliphilic properties. In conclusion, on the basis of the phenotypic features and phylogenetic independence described above, the novel isolates should be classified as a new genus composed of two novel species. We propose the name Halolactibacillus halophilus gen. nov., sp. nov. for phenotype 1 as the type species of this genus and Halolactibacillus miurensis sp. nov. for phenotype 2 .

\section{Description of Halolactibacillus gen. nov.}

Halolactibacillus [Ha.lo.lac'ti.ba.cil'lus. Gr. n. hals salt (loving); L. n. lac lactis milk; L. masc. n. bacillus stick, a small rod; N.L. masc. n. Halolactibacillus salt (loving) lactic acid rodlet].

Cells are Gram-positive, non-sporulating, straight rods, occurring singly, in pairs or in short chains, and elongated. Motile with peritrichous flagella. Catalase- and oxidasenegative. Negative for nitrate reduction, production of ammonia from L-arginine, production of dextran from sucrose and DNase. Weakly hydrolyse starch. Do not hydrolyse casein. Growth does not occur in the absence of sugars. Slightly halophilic and highly halotolerant; the optimum $\mathrm{NaCl}$ concentration for growth is $2-3 \%(\mathrm{w} / \mathrm{v})$, with a range of $0-25.5 \%(\mathrm{w} / \mathrm{v})$. Alkaliphilic; the optimum $\mathrm{pH}$ for growth is $8 \cdot 0-9 \cdot 5$, with a range of $6 \cdot 0-10 \cdot 0$. Growth occurs between $5-10$ and $40 \cdot 0-45 \cdot 0{ }^{\circ} \mathrm{C}$, with an optimum at $30-40{ }^{\circ} \mathrm{C}$. In anaerobic cultivation, L-lactic acid is the major end-product from glucose. Considerable amounts of formate, acetate and ethanol are produced in a molar ratio of approximately $2: 1: 1$, without gas production. Carbohydrates and related compounds are aerobically metabolized to acetate and pyruvate, as well as lactate. The cell-wall peptidoglycan is meso-diaminopimelic acid. Major cellular fatty acids are $a-C_{13: 0}$ and $C_{16: 0}$. Respiratory quinones and cytochromes are absent. The $\mathrm{G}+\mathrm{C}$ content of the DNA is 
Table 4. Characteristics that distinguish the isolates from other members of the HA group in Bacillus rRNA group 1, M. psychrotolerans and Alkalibacterium olivapovliticus

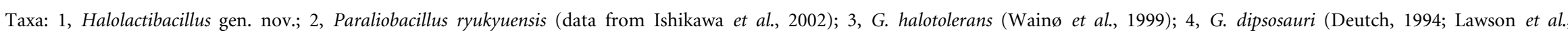

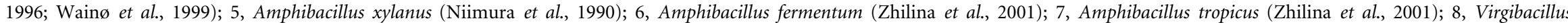

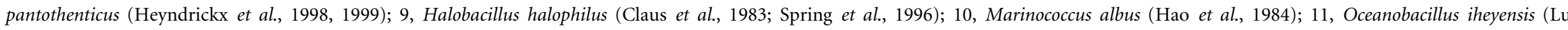

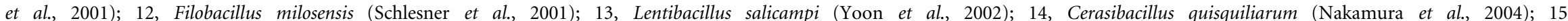

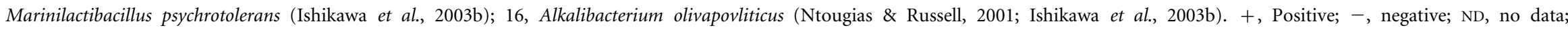
ANR, anaerobic respiration; Asp, aspartic acid; F, fermentation; Glu, glutamic acid; $m$-Dpm, meso-diaminopimelic acid; Orn, ornithine.

\begin{tabular}{|c|c|c|c|c|c|c|c|c|c|c|c|c|c|c|c|c|}
\hline Characteristic & 1 & 2 & 3 & 4 & 5 & 6 & 7 & 8 & 9 & 10 & 11 & 12 & 13 & 14 & 15 & 16 \\
\hline Cell morphology & Rods & Rods & Rods & Rods & Rods & Rods & Rods & Rods & Cocci & Cocci & Rods & Rods & Rods & Rods & Rods & Rods \\
\hline Spore formation & - & + & + & + & + & $t^{*}$ & + & + & + & - & + & + & + & + & - & - \\
\hline Anaerobic growth & $+(\mathrm{F})$ & $+(\mathrm{F})$ & - & $+(\mathrm{ANR})$ & $+(\mathrm{F})$ & $+(\mathrm{F})$ & $+(\mathrm{F})$ & $+(\mathrm{F})$ & - & - & - & - & - & - & $+(\mathrm{F})$ & $+(\mathrm{F})$ \\
\hline Catalase & - & $+\dagger$ & + & + & - & + & + & + & + & + & + & + & + & + & - & - \\
\hline $\begin{array}{l}\text { Glucose requirement } \\
\text { in aerobic cultivation } \\
\mathrm{NaCl}(\%) \text { : }\end{array}$ & + & + & - & - & + & + & + & - & - & - & - & - & - & - & $\mathrm{ND}$ & $\mathrm{ND}$ \\
\hline Range & $0-25 \cdot 5$ & $0-22$ & $0-20$ & $0-18 \cdot 6(\mathrm{KCl})$ & $<6$ & $1 \cdot 0-19 \cdot 7$ & $1 \cdot 0-20 \cdot 9$ & 0 to $\geqslant 10$ & $2-15$ & $5-20$ & $0-21$ & $2-23$ & $2-23$ & $<10$ & $0-20$ & $3-15$ \\
\hline Opt. & $2-3$ & $0 \cdot 75-3$ & 0 & $3 \cdot 7(\mathrm{KCl})$ & $\mathrm{ND}$ & $10 \cdot 8$ & $5 \cdot 4-10 \cdot 8$ & 4 & ND & $5-15$ & 3 & $8-14$ & $4-8$ & 0.5 & $2 \cdot 0-3 \cdot 75$ & $3-5 \ddagger$ \\
\hline \multicolumn{17}{|l|}{ pH: } \\
\hline Range & $6-10$ & $5 \cdot 5-9 \cdot 5$ & $5-10$ & 6 to $\geqslant 10$ & $8-10$ & $7-10 \cdot 5$ & $8 \cdot 5-11 \cdot 5$ & $\mathrm{ND}$ & $7-9$ & $\mathrm{ND}$ & $6 \cdot 5-10$ & $6 \cdot 5-8 \cdot 9$ & $>5$ & $7 \cdot 5-10$ & $6 \cdot 0-10 \cdot 0$ & $8 \cdot 5-10 \cdot 8$ \\
\hline Opt. & $8-9 \cdot 5$ & $7-8 \cdot 5$ & $7 \cdot 5$ & $7 \cdot 5$ & ND & $8 \cdot 5-9$ & $9 \cdot 5-9 \cdot 7$ & 7 & $7 \cdot 8$ & ND & $7-9 \cdot 5$ & $7 \cdot 3-7 \cdot 8$ & $6-8$ & $8-9$ & $8 \cdot 5-9 \cdot 0$ & $9 \cdot 0-10 \cdot 2$ \\
\hline $\begin{array}{l}\text { Major isoprenoid } \\
\text { quinones }\end{array}$ & None & MK-7 & MK-7 & MK-7 & None & ND & ND & MK-7 & MK-7 & MK-7 & MK-7 & $\mathrm{ND}$ & MK-7 & MK-7 & None & None \\
\hline Peptidoglycan type & $m$-Dpm & $m$-Dpm & $m$-Dpm & $m$-Dpm & $m$-Dpm & $\mathrm{ND}$ & $\mathrm{ND}$ & $m$-Dpm & Orn-D-Asp & $m$-Dpm & $\mathrm{ND}$ & Orn-D-Glu & $m$-Dpm & $m$-Dpm & Orn-D-Glu & Orn-D-Asp \\
\hline $\mathrm{G}+\mathrm{C}$ content $(\mathrm{mol} \%)$ & $38 \cdot 5-40 \cdot 7$ & $35 \cdot 6$ & 38 & $39 \cdot 4$ & $36-38$ & $41 \cdot 5$ & $39 \cdot 2$ & $38 \cdot 3$ & $40 \cdot 1-40 \cdot 9$ & $43 \cdot 9-46 \cdot 6$ & $35 \cdot 8$ & 35 & 44 & $35 \cdot 5$ & $34 \cdot 6-36 \cdot 2$ & $39 \cdot 7 \pm 1 \cdot 0$ \\
\hline $\begin{array}{l}\text { Major cellular fatty } \\
\text { acids }\end{array}$ & $\begin{array}{l}\mathrm{a}-\mathrm{C}_{13: 0} \\
\mathrm{C}_{16: 0}\end{array}$ & ND & $\begin{array}{l}a-C_{15: 0} \\
C_{16: 0} \\
a-C_{17: 0}\end{array}$ & $\begin{array}{c}\mathrm{i}-\mathrm{C}_{15: 0} \\
\text { a- } \mathrm{C}_{15: 0} \\
\mathrm{C}_{16: 0} \\
\mathrm{a}-\mathrm{C}_{17: 0}\end{array}$ & $\begin{array}{l}a-C_{15: 0} \\
C_{16: 0} \\
i-C_{16: 0}\end{array}$ & ND & ND & $\begin{array}{l}\mathrm{i}-\mathrm{C}_{15: 0} \\
\mathrm{a}-\mathrm{C}_{15: 0} \\
\mathrm{a}-\mathrm{C}_{17: 0}\end{array}$ & ND & $\begin{array}{l}a-C_{15: 0}, \\
a-C_{17: 0}\end{array}$ & $\begin{array}{l}\mathrm{i}-\mathrm{C}_{15: 0} \\
\mathrm{a}-\mathrm{C}_{15: 0} \\
\mathrm{i}-\mathrm{C}_{14: 0}\end{array}$ & $\mathrm{ND}$ & $\begin{array}{l}a-C_{15: 0}, \\
i-C_{16: 0}\end{array}$ & $\mathrm{i}-\mathrm{C}_{15: 0}$ & $\begin{array}{c}\mathrm{C}_{16: 0} \\
\mathrm{C}_{16: 1} \Delta 9 \\
\mathrm{C}_{18: 1} \Delta 9\end{array}$ & $\begin{array}{l}\mathrm{C}_{16: 0} \\
\mathrm{C}_{16: 1} \Delta 7\end{array}$ \\
\hline Isolation source & $\begin{array}{l}\text { Decaying } \\
\text { marine algae, } \\
\text { living sponge }\end{array}$ & $\begin{array}{c}\text { Decaying } \\
\text { marine alga }\end{array}$ & $\begin{array}{l}\text { Surface mud, } \\
\text { Great Salt } \\
\text { Lake }\end{array}$ & $\begin{array}{c}\text { Nasal salt } \\
\text { glands of a } \\
\text { desert iguana }\end{array}$ & $\begin{array}{c}\text { Alkaline } \\
\text { manure with } \\
\text { grass and } \\
\text { rice straw }\end{array}$ & $\begin{array}{l}\text { Sediment, } \\
\text { soda lake }\end{array}$ & $\begin{array}{l}\text { Sediment, } \\
\text { soda lake }\end{array}$ & Soils & $\begin{array}{l}\text { Salt marsh } \\
\text { soils }\end{array}$ & $\begin{array}{c}\text { Solar } \\
\text { saltern }\end{array}$ & $\begin{array}{l}\text { Mud, Iheya } \\
\text { Ridge }\end{array}$ & $\begin{array}{c}\text { Beach } \\
\text { sediment }\end{array}$ & Salt field & $\begin{array}{l}\text { Decomposing } \\
\text { system of } \\
\text { kitchen refuse }\end{array}$ & $\begin{array}{c}\text { Decaying } \\
\text { marine algae, } \\
\text { living sponge }\end{array}$ & $\begin{array}{c}\text { Wash-waters } \\
\text { of edible } \\
\text { olives }\end{array}$ \\
\hline
\end{tabular}

* Spore formation was not observed but culture survived heating.

$\dagger$ Produced in aerobic cultivation.

$\ddagger$ Optimum for the type strain. 
$38 \cdot 5-40 \cdot 7 \mathrm{~mol} \%$. The type species is Halolactibacillus halophilus. As determined by $16 \mathrm{~S}$ rRNA gene sequence analysis, the genus Halolactibacillus is located within the phylogenetic group composed of halophilic/halotolerant/alkaliphilic and/ or alkalitolerant species in Bacillus rRNA group 1.

\section{Description of Halolactibacillus halophilus sp. nov.}

Halolactibacillus halophilus (ha.lo.phi'lus. Gr. n. hals salt; Gr. adj. philos loving; N.L. masc. adj. halophilus salt loving).

This species has all the characteristics that define the genus. In addition, it has the characteristics described below. Deep colonies in $2.5 \% \mathrm{NaCl}$ glucose-yeast extract-peptone-fish extract agar medium are pale-yellow and lenticular, with diameters of $2-4 \mathrm{~mm}$ after 3 days at $30^{\circ} \mathrm{C}$. Surface colonies are round, convex, entire, pale-yellow and transparent, with diameters of $0.8-1 \cdot 0 \mathrm{~mm}$ after 3 days at $30^{\circ} \mathrm{C}$. Cells are $0 \cdot 6-0 \cdot 9 \times 3 \cdot 6-4 \cdot 5 \mu \mathrm{m}$, occurring singly, in pairs or in short chains. The optimum $\mathrm{NaCl}$ concentration for growth is $2 \cdot 0-3 \cdot 0 \%$, with a range of 0 to $23 \cdot 5-24 \cdot 0 \%$. The optimum $\mathrm{pH}$ for growth is $8 \cdot 0-9 \cdot 0$, with a range of $6 \cdot 5-9 \cdot 5$. Growth occurs between 5-10 and $40{ }^{\circ} \mathrm{C}$, with an optimum at 30 $37^{\circ} \mathrm{C}$. Lactic acid is the major fermentation product from glucose: $40-50 \%$ of glucose consumed is converted to formate, acetate and ethanol. Lactate yield decreases at higher $\mathrm{pH}$ of the fermentation medium. The following carbohydrates and related compounds are fermented: Dribose, D-glucose, D-fructose, D-galactose, D-mannose, Dcellobiose, lactose, maltose, melibiose, sucrose, D-raffinose, D-salicin, D-trehalose, D-mannitol, methyl $\alpha$-D-glucoside, glycerol, starch and sodium gluconate. L-Arabinose, Darabinose, D-xylose, D-rhamnose, D-melezitose, D-sorbitol, dulcitol, myo-inositol, adonitol and inulin are not fermented. The G + C content of the DNA is $39 \cdot 6-40 \cdot 7 \mathrm{~mol} \%$.

The type strain is M2-2 $2^{\mathrm{T}}\left(=\mathrm{DSM} 17073^{\mathrm{T}}=\mathrm{IAM} 15242^{\mathrm{T}}=\right.$ NBRC $100868^{\mathrm{T}}=$ NRIC $\left.0628^{\mathrm{T}}\right)$. Isolated from decaying marine algae and a living sponge collected at Oura beach, Miura Peninsula, Kanagawa Prefecture, Japan. The G+C content of the type strain is $40 \cdot 2 \mathrm{~mol} \%$.

\section{Description of Halolactibacillus miurensis sp. nov.}

Halolactibacillus miurensis (mi.u.ren'sis. N.L. masc. adj. miurensis from the Miura Peninsula, Japan, where the strains were isolated).

This species has all the characteristics that define the genus. In addition, it has the characteristics described below. Deep colonies in $2.5 \% \mathrm{NaCl}$ glucose-yeast extract-peptone-fish extract agar medium are pale-yellow and lenticular, with diameters of $2-4 \mathrm{~mm}$ after 3 days at $30{ }^{\circ} \mathrm{C}$. Surface colonies are round, convex, entire, pale-yellow and transparent, with diameters of $1.0-1.5 \mathrm{~mm}$ after 3 days at $30^{\circ} \mathrm{C}$. Cells are $0 \cdot 6-0 \cdot 9 \times 3 \cdot 6-4.5 \mu \mathrm{m}$, occurring singly, in pairs or short chains. The optimum $\mathrm{NaCl}$ concentration for growth is $2 \cdot 5-3 \cdot 0 \%(\mathrm{w} / \mathrm{v})$, with a range of $0-25 \cdot 5 \%$. The optimum
$\mathrm{pH}$ for growth is $9 \cdot 5$, with a range of $6 \cdot 0-6 \cdot 5$ to $10 \cdot 0$. Growth occurs at $5-45^{\circ} \mathrm{C}$, with an optimum at $37-40^{\circ} \mathrm{C}$. Lactic acid is the major fermentation product from glucose: $40-50 \%$ of glucose consumed is converted to formate, acetate and ethanol. Lactate yield decreases at higher $\mathrm{pH}$ of the fermentation medium. The following carbohydrates and related compounds are fermented: L-arabinose, D-ribose, Dxylose, D-glucose, D-fructose, D-galactose, D-mannose, Dcellobiose, lactose, maltose, melibiose, sucrose, D-raffinose, D-salicin, D-trehalose, D-melezitose, D-mannitol, methyl $\alpha$ D-glucoside, glycerol (weak), inulin, starch and sodium gluconate. D-Arabinose, D-rhamnose, D-sorbitol, dulcitol, myo-inositol and adonitol are not fermented. The $\mathrm{G}+\mathrm{C}$ content of the DNA is $38 \cdot 5-40 \cdot 0 \mathrm{~mol} \%$.

The type strain is strain M23- $1^{\mathrm{T}}\left(=\mathrm{DSM} 17074^{\mathrm{T}}=\mathrm{IAM}\right.$ $15247^{\mathrm{T}}=$ NBRC $100873^{\mathrm{T}}=$ NRIC $\left.0633^{\mathrm{T}}\right)$. Isolated from decaying alga at Oura beach, Miura Peninsula, Kanagawa Prefecture, Japan. The $\mathrm{G}+\mathrm{C}$ content of the type strain is $38 \cdot 5 \mathrm{~mol} \%$.

\section{Acknowledgements}

We are grateful to Masayuki Suzuki and Keiichi Goto, Mitsui Norin Co., Ltd for the fatty acid analysis, to Yoichi Niimura, Faculty of Applied Bio-Science, Tokyo University of Agriculture, for cytochrome analysis, and to Hajime Kanamori and Shihomi Ishizaki, Faculty of Applied Bio-Science, Tokyo University of Agriculture, for technical assistance.

\section{References}

Ash, C., Farrow, J. A. E., Wallbanks, S. \& Collins, M. D. (1991). Phylogenetic heterogeneity of the genus Bacillus revealed by comparative analysis of small-subunit-ribosomal RNA sequences. Lett Appl Microbiol 13, 202-206.

Axelsson, L. T. (1993). Lactic acid bacteria: classification and physiology. In Lactic Acid Bacteria, pp. 1-63. Edited by S. Salminen \& A. von Wright. New York: Marcel Dekker.

Brosius, J., Palmer, M. L., Kennedy, P. J. \& Noller, H. F. (1978). Complete nucleotide sequence of a $16 \mathrm{~S}$ ribosomal RNA gene from Escherichia coli. Proc Natl Acad Sci U S A 75, 4801-4805.

Bryan-Jones, D. G. \& Whittenbury, R. (1969). Haematin-dependent oxidative phosphorylation in Streptococcus faecalis. J Gen Microbiol 58, 247-260.

Carlsson, J. \& Griffith, C. J. (1974). Fermentation products and bacterial yields in glucose-limited and nitrogen-limited cultures of streptococci. Arch Oral Biol 19, 1105-1109.

Claus, D., Fahmy, F., Rolf, H. J. \& Tosunoglu, N. (1983). Sporosarcina halophila sp. nov., an obligate, slightly halophilic bacterium from salt marsh soils. Syst Appl Microbiol 4, 496-506.

Collins, M. D., Lund, B. M., Farrow, J. A. E. \& Schleifer, K.-H. (1983). Chemotaxonomic study of an alkalophilic bacterium, Exiguobacterium aurantiacum gen. nov., sp. nov. J Gen Microbiol 129, 2037-2042.

Deutch, C. E. (1994). Characterization of a novel salt-tolerant Bacillus sp. from the nasal cavities of desert iguanas. FEMS Microbiol Lett 121, 55-60.

Ezaki, T., Hashimoto, Y. \& Yabuuchi, E. (1989). Fluorometric deoxyribonucleic acid-deoxyribonucleic acid hybridization in 
microdilution wells as an alternative to membrane filter hybridization in which radioisotopes are used to determine genetic relatedness among bacterial strains. Int J Syst Bacteriol 39, 224-229.

Felsenstein, J. (1981). Evolutionary trees from DNA sequences: a maximum likelihood approach. J Mol Evol 17, 368-376.

Felsenstein, J. (1985). Confidence limits on phylogenies: an approach using the bootstrap. Evolution 39, 783-791.

Fukui, K., Kato, K., Kodama, T., Ohta, H., Shimamoto, T. \& Shimono, T. (1988). Kinetic study of a change in intracellular ATP level associated with aerobic catabolism of ethanol by Streptococcus mutans. J Bacteriol 170, 4589-4593.

Garabito, M. J., Arahal, D. R., Mellado, E., Márquez, M. C. \& Ventosa, A. (1997). Bacillus salexigens sp. nov., a new moderately halophilic Bacillus species. Int J Syst Bacteriol 47, 735-741.

Gatesoupe, F.-J. (1999). The use of probiotics in aquaculture. Aquaculture 180, 147-165.

Gee, J. M., Lund, B. M., Metcalf, G. \& Peel, J. L. (1980). Properties of a new group of alkalophilic bacteria. J Gen Microbiol 117, 9-17.

Gerhardt, P., Murray, R. G. E., Wood, W. A. \& Kreig, N. R. (1994). Methods for General and Molecular Bacteriology. Washington, DC: American Society for Microbiology.

Gunsalus, I. C. \& Niven, C. F., Jr (1942). The effect of $\mathrm{pH}$ on the lactic acid fermentation. $J$ Biol Chem 145, 131-136.

Hao, M. V., Kocur, M. \& Komagata, K. (1984). Marinococcus gen. nov., a new genus for motile cocci with meso-diaminopimelic acid in the cell wall; and Marinococcus albus sp. nov. and Marinococcus halophilus (Novitsky and Kushner) comb. nov. J Gen Appl Microbiol 30, 449-459.

Hasegawa, T., Takizawa, M. \& Tanida, S. (1983). A rapid analysis for chemical grouping of aerobic actinomycetes. J Gen Appl Microbiol 29, 319-322.

Heyndrickx, M., Lebbe, L., Kersters, K., De Vos, P., Forsyth, G. \& Logan, N. A. (1998). Virgibacillus: a new genus to accommodate Bacillus pantothenticus (Proom and Knight 1950). Emended description of Virgibacillus pantothenticus. Int J Syst Bacteriol 48, 99-106.

Heyndrickx, M., Lebbe, L., Kersters, K., Hoste, B., De Wachter, R., De Vos, P., Forsyth, G. \& Logan, N. A. (1999). Proposal of Virgibacillus proomii sp. nov. and emended description of Virgibacillus pantothenticus (Proom and Knight 1950) Heyndrickx et al. 1998. Int J Syst Bacteriol 49, 1083-1090.

lizuka, H. \& Yamasato, K. (1959). Pediococcus soyae nov. sp., main lactic acid bacterium in "shoyu moromi". J Gen Appl Microbiol 5, 58-73.

Inagaki, F., Suzuki, M., Takai, K., Oida, H., Sakamoto, T., Aoki, K., Nealson, K. H. \& Horikoshi, K. (2003). Microbial communities associated with geological horizons in coastal subseafloor sediments from the Sea of Okhotsk. Appl Environ Microbiol 69, 7224-7235.

Ishikawa, M., Ishizaki, S., Yamamoto, Y. \& Yamasato, K. (2002). Paraliobacillus ryukyuensis gen. nov., sp. nov., a new Gram-positive, slightly halophilic, extremely halotolerant, facultative anaerobe isolated from a decomposing marine alga. J Gen Appl Microbiol 48, 269-279.

Ishikawa, M., Ishizaki, S., Yamamoto, Y. \& Yamasato, K. (2003a). Paraliobacillus ryukyuensis gen. nov., sp. nov. In Validation of Publication of New Names and New Combinations Previously Effectively Published Outside the IJSEM, List no. 91. Int J Syst Evol Microbiol 53, 627-628.

Ishikawa, M., Nakajima, K., Yanagi, M., Yamamoto, Y. \& Yamasato, K. (2003b). Marinilactibacillus psychrotolerans gen. nov., sp. nov., a halophilic and alkaliphilic marine lactic acid bacterium isolated from marine organisms in temperate and subtropical areas of Japan. Int J Syst Evol Microbiol 53, 711-720.
Jones, B. E., Grant, W. D., Collins, N. C. \& Mwatha, W. E. (1994). Alkaliphiles: diversity and identification. In Bacterial Diversity and Systematics, pp. 195-230. Edited by F. G. Priest, A. RamosCormenzana \& B. J. Tindall. New York: Plenum.

Kandler, O. \& Weiss, N. (1986). Regular, nonsporing Gram-positive rods. In Bergey's Manual of Systematic Bacteriology, vol. 2, pp. 1208-1260. Edited by P. H. A. Sneath, N. S. Mair, M. E. Sharpe \& J. G. Holt. Baltimore: Williams \& Wilkins.

Kandler, O., Schillinger, U. \& Weiss, N. (1983). Lactobacillus halotolerans sp. nov., nom. rev. and Lactobacillus minor sp. nov., nom. rev. Syst Appl Microbiol 4, 280-285.

Kimura, M. (1980). A simple method for estimating evolutionary rates of base substitutions through comparative studies of nucleotide sequences. J Mol Evol 16, 111-120.

Kushner, D. J. (1978). Life in high salt and solute concentrations: halophilic bacteria. In Microbial Life in Extreme Environments, pp. 318-346. Edited by D. J. Kushner. London: Academic Press.

Kushner, D. J. \& Kamekura, M. (1988). Physiology of halophilic eubacteria. In Halophilic Bacteria, vol. I, pp. 109-140. Edited by F. Rodríguez-Valera. Boca Raton, FL: CRC Press.

Lawson, P. A., Deutch, C. E. \& Collins, M. D. (1996). Phylogenetic characterization of a novel salt-tolerant Bacillus species: description of Bacillus dipsosauri sp. nov. J Appl Bacteriol 81, 109-112.

Liu, J.-R., Tanner, R. S., Schumann, P. \& 7 other authors (2002). Emended description of the genus Trichococcus, description of Trichococcus collinsii sp. nov., and reclassification of Lactosphaera pasteurii as Trichococcus pasteurii comb. nov. and of Ruminococcus palustris as Trichococcus palustris comb. nov. in the low-G + C Grampositive bacteria. Int J Syst Evol Microbiol 52, 1113-1126.

Lu, J., Nogi, Y. \& Takami, H. (2001). Oceanobacillus iheyensis gen. nov., sp. nov., a deep-sea extremely halotolerant and alkaliphilic species isolated from a depth of $1050 \mathrm{~m}$ on the Iheya Ridge. FEMS Microbiol Lett 205, 291-297.

Marmur, J. (1961). A procedure for the isolation of deoxyribonucleic acid from micro-organisms. J Mol Biol 3, 208-218.

Morishita, T., Tamura, N., Makino, T. \& Kudo, S. (1999). Production of menaquinones by lactic acid bacteria. J Dairy Sci 82, 1897-1903.

Nakagawa, A. \& Kitahara, K. (1959). Taxonomic studies on the genus Pediococcus. J Gen Appl Microbiol 5, 95-126.

Nakamura, K., Haruta, S., Ueno, S., Ishii, M., Yokota, A. \& Igarashi, Y. (2004). Cerasibacillus quisquiliarum gen. nov., sp. nov., isolated from a semi-continuous decomposing system of kitchen refuse. Int J Syst Evol Microbiol 54, 1063-1069.

Niimura, Y., Yanagida, F., Uchimura, T., Ohara, N., Suzuki, K. \& Kozaki, M. (1987). A new facultative anaerobic xylan-using alkalophile lacking cytochrome, quinone, and catalase. Agric Biol Chem 51, 2271-2275.

Niimura, Y., Koh, E., Uchimura, T., Ohara, N. \& Kozaki, M. (1989). Aerobic and anaerobic metabolism in a facultative anaerobe Ep01 lacking cytochrome, quinone and catalase. FEMS Microbiol Lett 61, 79-84.

Niimura, Y., Koh, E., Yanagida, F., Suzuki, K.-i., Komagata, K. \& Kozaki, M. (1990). Amphibacillus xylanus gen. nov., sp. nov., a facultatively anaerobic sporeforming xylan-digesting bacterium which lacks cytochrome, quinone, and catalase. Int J Syst Bacteriol 40, 297-301.

Ntougias, S. \& Russell, N. J. (2001). Alkalibacterium olivoapovliticus gen. nov., sp. nov., a new obligately alkaliphilic bacterium isolated from edible-olive wash-waters. Int J Syst Evol Microbiol 51, $1161-1170$

Ohama, T. (1982). Cytochromes. In Biseibustu-no Kagakubunrui Jikkenho (Manual of Microbial Chemosystematics), pp. 210-224. 
Edited by K. Komagata. Tokyo: Gakkai Shuppan Senta (Japan Scientific Societies Press) (in Japanese).

Okada, S., Uchimura, T. \& Kozaki, M. (1992). Nyusankin Jikken Manyuaru (Laboratory Manual for Lactic Acid Bacteria). Tokyo: Asakura-shoten (in Japanese).

Olsen, G. J., Matsuda, H., Hagstrom, R. \& Overbeek, R. (1984). fastDNAml: a tool for construction of phylogenetic trees of DNA sequences using maximum likelihood. Comput Appl Biosci 10, 41-48.

Pritchard, G. G. \& Wimpenny, J. W. T. (1978). Cytochrome formation, oxygen-induced proton extrusion and respiratory activity in Streptococcus faecalis var. zymogenes grown in the presence of haematin. J Gen Microbiol 104, 15-22.

Rhee, S. K. \& Pack, M. Y. (1980). Effect of environmental pH on fermentation balance of Lactobacillus bulgaricus. J Bacteriol 144, 217-221.

Ringø, E. \& Gatesoupe, F.-J. (1998). Lactic acid bacteria in fish: a review. Aquaculture 160, 177-203.

Saito, H. \& Miura, K. (1963). Preparation of transforming deoxyribonucleic acid by phenol treatment. Biochim Biophys Acta 72, 619-629.

Saitou, N. \& Nei, M. (1987). The neighbor-joining method: a new method for reconstructing phylogenetic trees. Mol Biol Evol 4, 406-425.

Sakamoto, M. \& Komagata, K. (1996). Aerobic growth of and activities of NADH oxidase and NADH peroxidase in lactic acid bacteria. J Ferment Bioeng 82, 210-216.

Satomi, M., Kimura, B., Mizoi, M., Sato, T. \& Fujii, T. (1997). Tetragenococcus muriaticus sp. nov., a new moderately halophilic lactic acid bacterium isolated from fermented squid liver sauce. Int J Syst Bacteriol 47, 832-836.

Schlesner, H., Lawson, P. A., Collins, M. D., Weiss, N., Wehmeyer, U., Völker, H. \& Thomm, M. (2001). Filobacillus milensis gen. nov., sp. nov., a new halophilic spore-forming bacterium with Orn-D-Glutype peptidoglycan. Int J Syst Evol Microbiol 51, 425-431.

Somogyi, M. (1945). A new reagent for the determination of sugars. J Biol Chem 160, 61-68.

Spring, S., Ludwig, W., Marquez, M. C., Ventosa, A. \& Schleifer, K.-H. (1996). Halobacillus gen. nov., with descriptions of Halobacillus litoralis sp. nov. and Halobacillus trueperi sp. nov., and transfer of Sporosarcina halophila to Halobacillus halophilus comb. nov. Int J Syst Bacteriol 46, 492-496.
Tamaoka, J. \& Komagata, K. (1984). Determination of DNA base composition by reverse-phase high-performance liquid chromatography. FEMS Microbiol Lett 25, 125-128.

Thompson, J. D., Gibson, T. J., Plewniak, F., Jeanmougin, F. \& Higgins, D. G. (1997). The CLUSTAL_X Windows interface: flexible strategies for multiple sequence alignment aided by quality analysis tools. Nucleic Acids Res 25, 4876-4882.

Toffin, L., Zink, K., Kato, C., Pignet, P., Bidault, A., Bienvenu, N., Birrien, J.-L. \& Prieur, D. (2005). Marinilactibacillus piezotolerans sp. nov., a novel marine lactic acid bacterium isolated from deep subseafloor sediment of the Nankai Trough. Int J Syst Evol Microbiol 55, 345-351.

Wainø, M., Tindall, B. J., Schumann, P. \& Ingvorsen, K. (1999). Gracilibacillus gen. nov., with description of Gracilibacillus halotolerans gen. nov., sp. nov.; transfer of Bacillus dipsosauri to Gracilibacillus dipsosauri comb. nov., and Bacillus salexigens to the genus Salibacillus gen. nov., as Salibacillus salexigens comb. nov. Int J Syst Bacteriol 49, 821-831.

Wang, H., Baldwin, K. A. O’Sullivan D. J. \& McKay, L. L. (2000). Identification of a gene cluster encoding Krebs cycle oxidative enzymes linked to the pyruvate carboxylase gene in Lactococcus lactis ssp. lactis C2. J Dairy Sci 83, 1912-1918.

Whittenbury, R. (1964). Hydrogen peroxide formation and catalase activity in the lactic acid bacteria. J Gen Microbiol 35, 13-26.

Yamada, T. \& Carlsson, J. (1975). Regulation of lactate dehydrogenase and change of fermentation products in streptococci. J Bacteriol 124, 55-61.

Yanagi, M. \& Yamasato, K. (1993). Phylogenetic analysis of the family Rhizobiaceae and related bacteria by sequencing of 16 S rRNA gene using PCR and DNA sequencer. FEMS Microbiol Lett 107, 115-120.

Yoon, J.-H., Kang, K. H. \& Park, Y.-H. (2002). Lentibacillus salicampi gen. nov., sp. nov., a moderately halophilic bacterium isolated from a salt field in Korea. Int J Syst Evol Microbiol 52, 2043-2048.

Zhilina, T. N., Garnova, E. S., Tourova, T. P., Kostrikina, N. A. \& Zavarzin, G. A. (2001). Amphibacillus fermentum sp. nov., Amphibacillus tropicus sp. nov., new alkaliphilic, facultatively anaerobic, saccharolytic bacilli from Lake Magadi. Microbiology (English translation of Mikrobiologiia) 70, 711-722.

Zhilina, T. N., Garnova, E. S., Tourova, T. P., Kostrikina, N. A. \& Zavarzin, G. A. (2002). Amphibacillus fermentum sp. nov. and Amphibacillus tropicus sp. nov. In Validation of Publication of New Names and New Combinations Previously Effectively Published Outside the IJSEM, List no. 85. Int J Syst Evol Microbiol 52, 685-690. 